DOI https://doi.org/10.36059/978-966-397-121-6/248-276

\title{
THE RIGHT OF CITIZENS TO ENVIRONMENTAL EDUCATION AS A FACTOR OF ENVIRONMENTALIZATION OF LEGISLATION ON EDUCATION IN UKRAINE
}

\author{
Slepchenko A. A.
}

\section{INTRODUCTION}

From the second half of the 20th century, the problems of environmental education and enlightment became the object of active attention of the international community, democratic society, scientific and educational community, religious organizations. There has been widespread awareness that environmental education is one of the most effective instruments for ensuring environmental safety. Environmental education, the goal of which is balanced, environmentally safe development of mankind and high level of environmental culture of all the social groups within society, has taken one of the first places among the environmental priorities of humanity.

The progressive achievement of the Ukrainian environmental and legal doctrine in this area is the enshrinement of right of citizens to environmental education as one of the environmental rights of citizens in Art. 9 of the Law of Ukraine 'On Environmental Protection' dated June 25, 1991. It is worth to nore that neither the Constitution of Ukraine in force at that moment nor the international legal documents on human rights included environmental rights in the system of human rights and citizen at that time. As prof. M.V. Krasnova suggested. such a progressive conflict of norms reflected in the Ukrainian domestic legislation was due to the necessity of determining the highest universal value of a person, protecting his life and health, and establishing a system of guarantees for the realization and protection of these rights ${ }^{1}$.

An explicitly outlined list of internationally recognised environmental rights is still absent today. Although prospects of international legal

${ }^{1}$ Краснова М. В. Конституція України та екологічні права громадян. Вісник Київського національного університету ім. Тараса Шевченка. Юридичні науки. 2000. № 8. C. $12-13,16$. 
consolidation of environmental rights exist. For example, the list of such rights is proposed in the Draft Principles on Human Rights and the Environment ${ }^{2}$, developed and proposed by an international group of experts led by F. Ksentini at the UN Office in Geneva in 1994. The draft declaration is one of the first international instruments, which fully addressed the problem of relationship between human rights and environment. The document demonstrates that the principles of environmental and fundamental human rights include the right of everyone to a safe, healthy and environmentally friendly environment, clearly distinguishing the environmental spectrum of a wide range of human rights ${ }^{3}$. Among the list of human rights and freedoms in the environmental sphere, the document also provides the right of all people to education in the field of environment and human rights (para. 17).

The study of mechanisms for implementing and ensuring the environmental rights of citizens in the Ukrainian environmental and legal doctrine is traditionally given great attention. Issues of environmental rights of citizens in general, individual environmental rights, including some aspects of the right to environmental education, were analysed by the representatives of environmental law doctrine, such as V.I. Andreytsev ${ }^{4}$, G.V. Anisimova5, G.I. Balyuk ${ }^{6}$, S.G. Gritskevich ${ }^{7}$, N.R. Kobetska ${ }^{8}$, M.V. Krasnova ${ }^{9}$, E.V. Poznyak ${ }^{10}$,

2 Draft Principles On Human Rights And The Environment, E/CN.4/Sub.2/1994/9, Annex I (1994). University of Minnesota Human Rights library. http://hrlibrary.umn.edu/instree/1994-dec.htm (дата звернення 10.06.2019).

3 Офіційний сайт екологічної організації «Зелений порятунок». URL: http://www.greensalvation.org/old/Russian/Publish/10_rus/10_16.htm (дата звернення 10.06.2019).

${ }^{4}$ Андрейцев В. І. Екологічне право. Курс лекцій : навч. посібник для юрид. фак. вузів. К: Вентурі; 1996. С.13; Андрейцев В. І. Новації еколого-правової освіти в Україні. Право України. 1998. № 5. С. 44-50.

${ }^{5}$ Анісімова Г.В. Здійснення громадянами екологічних прав : автрореф. дис. на здобуття наук. ступеня канд.юр.наук: 12.00.06. Харків: Національна юридична академія України ім. Ярослава Мудрого, 1996. С. 8-11.

${ }^{6}$ Балюк Г.І. Екологічне право України: Конспект лекцій у схемах (Загальна і Особлива частини) : Навч. посібник. К.: Юрінком Інтер, 2006. С. 21-23, 24-79; Балюк Г.І. Правове забезпечення екологічної складової сталого розвитку: проблеми законодавчого регулювання, створення екологічної столиці світу та удосконалення екологічної освіти в Україні. Вісник Київського Національного університету імені Тараса Шевченка. Серія «Юридичні науки». 2012. № 92. С. 12-13.

${ }^{7}$ Грицкевич С.Г. Конституційні екологічні права людини і громадянина та їх забезпечення органами внутрішніх справ : автореф. дис. ... канд.. юрид. наук: 12.00.06. К.: КНУ ім. Тараса Шевченка, 2002. 24 с.

${ }^{8}$ Кобецька Н.Р. Екологічне право України : навч. посібник. К., 2007. С. 38-56. 
A.A. Slepchenko ${ }^{11}$ and some others. However, in spite of the considerable attention of scholars to the field of environmental rights, the urgent need to continue scientific research in the field of improving the legal principles of environmental education, taking into account the global trends in this field, still exists. It is necessary to create an effective social and legal mechanism of environmental education, which will include the necessary legislative basis, institutional and financial provision, and guarantee the general environmental education at the level of environmental imperative. In its turn, it will create the preconditions for increasing the effectiveness of legal mechanism in the field of environmental relations in general, which is today the global environmental interest, the interest of every person, society and the state.

Environmental interest underlies the provision of environmentally sound life of society and the state ${ }^{12}$. The initial, starting point of environmental interests and needs of ordinary people is the possibility to use environmentally friendly environment, live in environmentally safe environment, receive clean products, reliable information about them and reimbursement of damage caused by environmental violations ${ }^{13}$. The environmental rights and freedoms of person and citizen are directed exactly at satisfaction of environmental interests. Awareness and consideration of the priority of environmental interests should become guidelines for the activities of public authorities in all the spheres of public life $^{14}$.

The right to environmental education has a special place in the system of environmental rights of citizens, since its implementation is not directly aimed at the use of natural resources, environmental

\footnotetext{
${ }^{9}$ Краснова М.В. Екологічні права та обов'язки громадян. Екологічне право України. Академічний курс : Підручник. К., 2005. С. 39-59; 197.

${ }^{10}$ Позняк Е.В. Культурна функція екологічного права: від декларативності до прийняття конкретних рішень. Вісник Начіональної юридичної академії України імені Ярослава Мудрого. 2012. № 3 (13). С. 210-215.

11 Слепченко А.А. Забезпечення права на екологічну освіту громадян в Україні : монографія. Чернівці: Кондратьєв А.В., 2017. 188 с.

${ }^{12}$ Орлов М. Правове забезпечення реалізації екологічних інтересів - основа належної охорони довкілля і розвитку економіки України. Право Украӥни. 2001. № 1. С. $68-72$.

${ }^{13}$ Грицкевич С. Екологічні права в системі конституційних прав людини i громадянина. Право Украӥни. 2001. № 8. С. 54-57.

${ }^{14}$ Краснова М. В. Конституція України та екологічні права громадян. Вісник Київського національного університету ім. Тараса Шевченка. Юридичні науки. 2000. № 8. C. 12-16; 20.
} 
protection or the provision of environmental safety. The implementation of this right is actually implemented in educational relations and affects the environment indirectly, indirectly, through the formation of a system of environmental knowledge, environmental competence, environmental consciousness, environmental thinking and human culture. Therefore, the right to environmental education should be reflected not only in the environmental one, but also in educational legislation, which will create legal guarantees for its implementation. The legislation on education should be ecologizated.

In Ukraine at the scientific level it has been proved that ecologization of education is an important part of the modernization of educational system in the contemporary Ukrainian society. Through the ecologization of education, the emergence of a new paradigm of humannature relations, the implementation of sustainable development, the adoption of values and norms of modern environmental culture, the formation of ecocentric consciousness, which should save society from an environmental catastrophe and help it to overcome existing environmental problems, actually occurs ${ }^{15}$.

The logical consequence of awareness in the Ukrainian society of the need to legislatively support the increase of environmental knowledge was the consolidation of such a strategic direction for the development of education in Ukraine as ecologization in the National Strategy for the Development of Education in Ukraine until 2021, approved by the Decree of the President of Ukraine dated June $25,2013^{16}$.

The next important step on this path was adoption of the new Law of Ukraine 'On Education'17 dated September 5, 2017. According ot Art. 6 of this Law, the principles of the state policy of Ukraine in the sphere of education and principles of educational activity, include the formation of a healthy lifestyle culture, environmental culture and a careful attitude towards the environment.

15 Большак Л.І. Екологізація освіти як соціальна потреба сучасного суспільства : автореф. дис. ... канд. філос. наук: 09.00.10 / Нац. пед. ун-т ім. М.П. Драгоманова. К., 2012. 20 с.

16 Про Національну стратегію розвитку освіти в Україні на період до 2021 року: Указ Президента України. Офіиійний вісник України. 2013. № 50. Ст. 1783.

${ }^{17}$ Про освіту: Закон України від 5 вересня 2017 р.. Офіційний вісник Украӥни. 2017. № 78. Ст. 2392. 


\section{Key Problems of Legal Regulation in the Sphere of Environmental Education in Ukraine}

Problems of environmental education, which is a complex phenomenon of interdisciplinary nature, are studied within the limits of their subjects mainly by humanities and natural sciences: ecology, biology, philosophy, pedagogy, psychology, culturology. In particular, philosophy explores the world-view aspects of planetary ecological safety, and pays considerable attention to issues of environmental education. Representatives of this sphere point out that environmental education is one of the important directions of comprehension by society of the surrounding world. An important prerequisite for development of the system of environmental knowledge is the creation of a new environmental theory, i.e. metaecology, the central position of which is the concept of the inseparability of a living organism from environment of its existence, because "without knowledge of the surrounding world, without awareness of the person and society of its place in the process of earthly and universal being none of the pressing problems of our time can not be solved properly, ${ }^{18}$.

Currently, the common task of legal science, philosophy, pedagogy, ecology and other scientific branch is the development of interdisciplinary scientific and methodological principles, concepts, doctrines of environmental enlightment and environmentalization of education in general, harmonization of their content, goals, tasks, including the concept of education for sustainable development, for which the Ukraine took the course. Conclusions as a result of the mentioned development should become a scientific basis for the improvement of the corresponding environmental and legal doctrine. In this regard, M.M. Brinchuk noted that knowledge of social sciences on interaction of society and nature are an independent methodological basis for development of environmental law. In this context sectoral sciences will serve to substantiate the provisions of environmental law, taking into account the most general laws of development of nature, society, thinking, patterns of mass behavior of people ${ }^{19}$.

\footnotetext{
${ }^{18}$ Маца К.О. Роль екологічної освіти в формуванні нового наукового світобачення. Людина і довкілля. Проблеми неоекології. 2000. Вип. 1. С. 10-15.

${ }^{19}$ Бринчук М.M. Внешние методологические основания развития экологического права: закономерности развития природы, положения общественных наук о взаимодействии общества и природы, потенциал природы. Экологическое право. 2011. № 1. С. 5-6.
} 
The positive consequence of increasing the attention of modern science to cross-sectoral research in the field of environmental education, culture and consciousness was the identification of a set of key issues, including legal ones, which impede progress in the development of this area. Today not only legal scholars recognize that the environmentalization of the modern system of education on a global scale requires qualitative legal regulation, the necessity of which is determined by the existence of a single social space on the planet, the space of a single nature (a system with numerous connections), which requires the inclusion of environmental content in all existing curricula ${ }^{20}$. The sphere of activity is crucial for the revitalization of environmental education and enlightment in Ukraine, the provision of appropriate legal forms of activity, the creation of a system of incentives and legal safeguards. However, the environmental law may not only guarantee its citizens, with its legal means, minimum level of environmental education for all citizens, since education is regulated by the legislation on education in Ukraine. These objective reasons gave rise to prof. V.I. Andreytsev refer the right to environmental education to a group of inter-branch environmental rights, i.e. those rights that are implemented on the inter-branch level ${ }^{21}$.

It is precise grounds for conclusion that legal regulation of this sphere of relations in Ukraine is far from perfect. By this time, a special legislative act on environmental education in Ukraine has not been adopted. The most important problems of a conceptual nature have not been solved yet. For example, there is no legislative definition of the concept of environmental education, that leads to ambiguous understanding of the boundaries and features of this phenomenon, there is a substitution of these concepts of related, but not identical phenomena such as environmental education and enlightment, environmental culture, environmental information, which does not contribute to the effective implementation of these types of environmental activities.

A clear and unambiguous understanding of the terms, concepts that define the analysed sphere, is known to be an important prerequisite for

20 Маркович Д.Ж. Глобализация и экологическое образование. Социиологические исследования. 2001. №1. С. 17, 20-23.

21 Андрейцев B.I. Екологічне право. Курс лекцій : навч. посібник для юрид. фак. вузів. К., 1996. С. 34. 
the effectiveness of legal regulation in a particular area. A characteristic feature of environmental law doctrine is that the rapid development of research in the field of interaction between society and nature has brought to life many new phenomena and social relations. The Concept of Environmental Education in Ukraine ${ }^{22}$ emphasized on the need for improvement, harmonization and standardization of terminology in the field of environmental knowledge as on one of the most important tasks in the field of the development of environmental education. Complexity and cross-sectoral nature of environmental sciences is one of the reasons for the existing diversity of understanding and interpretation of many concepts on which the environmental law doctrine is based and whose range continues to expand. The issues of the development of scientifically substantiated terminology do not lose their relevance and remain an important task of environmental and legal research, since the heterogeneity and contradictory approaches to definition of the concepts studied are an obstacle to improving the legal regulation of relations that arise in the field of environmental protection and environmental education as well.

Due to terminological uncertainty both in practice and doctrine, the term `environmental education` is often understood unreasonably widely, bearing in mind other phenomena in its legal nature such as environmental teaching, enlightment and propaganda, when environmental knowledge is provided in other forms, than training in educational institutions, as in lectures, clubs, institutions of the nature reserve fund, distribution of environmental information in libraries, mass media, etc. Sometimes environmental education refers even to advertising.

As noted above, current legislation of Ukraine still does not provide the concept of environmental education, enlightment and teaching are absent despite existing grounds for the future fixing of such terms. For example, in the draft law of Ukraine "On Environmental Education" dated October 16, 2002 submitted by the National Deputy of Ukraine O.M. Volkov', contained the following definition: 'environmental

${ }^{22}$ Концепція екологічної освіти в Україні, затверджена Рішенням Колегії Міністерства освіти і науки України № 13/6-19 від 20 грудня 2001 р. Інформаційний вісник. Вищза освіта. № 9. С. 50-61.

${ }^{23}$ Проект Закону України «Про екологічну освіту». URL: http://w1.c1.rada.gov.ua/pls/zweb2/webproc4_2?id=\&pf3516=2309\&skl=5 (дата звернення: 10.06.2017). 
education is a continuous process of education, training, self-education and personality development, aimed at forming norms of moral behavior of people, their responsibility in relation to the environment, as well as the acquisition of special knowledge and practical skills in the field of environmental protection, environmental management and environmental safety'. In our opinion, this definition is too broad in content.

The Concept of Environmental Education in Ukraine proposes the following definition: 'environmental education, as a holistic cultural phenomenon, which includes the processes of education, upbringing, development of the person, should be directed towards the formation of environmental culture as an integral part of the system of national and social education of all the social groups of the population of Ukraine, including through environmental education provided by nongovernmental environmental organizations, environmentalization of educational disciplines and training programs, as well as professional environmental training through basic environmental education'. This definition includes the education provided by public organizations, which are not subjects of educational activity under the legislation of Ukraine.

Examples of consolidating the definition of environmental education can be found in the legislation of some countries. For example, the Law of the Republic of Armenia 'On Environmental Education and Upbringing of the Population' dated December 17, 2001 ${ }^{24}$ establishes the following definition: 'environmental education is a continuous process aimed at transferring environmental knowledge to individuals and populations, on environmental education, rooting of environmental culture, on their correct and reasonable orientation, manifestation of abilities and formation of behavior in the field of nature conservation and nature management' (Art. 1).

The Law of the Republic of Azerbaijan 'On Environmental Education and Public Education' ${ }^{25}$ dated January 10, 2002 stipulates that 'environmental education is a process of teaching and studying

\footnotetext{
${ }^{24}$ Об экологическом образовании и воспитании населения: Закон Республики Армения от 20 ноября 2001 г. Официальный сайт Национального Собрания Республики Армения. URL: http://www.parliament.am/legislation.php?sel=show\&ID= $1741 \&$ lang=rus\# (дата звернення 10.06.2019)

${ }^{25}$ Об экологическом образовании и просвещении населения: Закон Азербайджанской Республики от 10 января 2002 г. URL: https://azertag.az/ru/xeber/ZAKON_AZERBAIDZHANSKOI_RESPUBLIKI_Ob_ekolog icheskom_obrazovanii_i_prosveshchenii_naseleniya-988078 (дата звернення 10.06.2019)
} 
norms, special knowledge, experience in the protection of the environment and the use of natural resources.' In accordance with Art. 1 of Law of the Republic of Tajikistan "On Environmental Education of the Population" ${ }^{26}$ dated December 29, 2010, 'environmental education is a learning process aimed at obtaining environmental knowledge, training, enlightment in the spirit of environmental education, development of environmental culture, correct and reasonable orientation, manifestation of abilities and the formation of the proper behavior of individuals and the population in the field of nature conservation and nature management.'

The problem of legislative consolidation of the notion of environmental education was further complicated by the emergence of the notion of 'education for sustainable development' as a meaningful new type of education in the modern world. The subject of broad discussions was the correlation such phenomena as "environmental education" and "education for sustainable development" both at national and international levels. It is often suggested that environmental education is a prerequisite or foundation for the emergence of education for sustainable development, since purpose and direction of environmental education is fully consistent with the goals of the concept of sustainable development.

Today as a result of the efforts of the international community, education for sustainable development was divided into a separate crosssectoral direction of international and regional cooperation and led to a significant increase of attention to environmental education activities. The leading role of environmental education on the path to sustainable development was recognized by the world community already in the 90 's of the 20 th century ${ }^{27}$. As noted in the doctrine, environmentalization of the educational process is becoming more and more important not only as a priority element of the mechanism of environmental safety, but also as an integrative factor of education in general, which, in the context of sustainable development, defines the strategic goal and the

\footnotetext{
${ }^{26}$ Об экологическом образовании населения: Закон Республики Таджикистан от 29 декабря 2010 г. URL: http://energo-cis.ru/wyswyg/file/Zakon/Nacional/ Tadghikistan/ob_ekologicheskom_obrazovanii_naseleniya.pdf (дата звернення 10.06.2019)

${ }^{27}$ Ибрагимов И.М. Основания экологического образования: философский анализ : автореф. дис. ... канд. филос. наук: 09.00.08. М., 1998. С. 18.
} 
leading directions of the latter ${ }^{28}$. Thus, there is growing interest in the problems of environmental education not only as of an independent direction of nature conservation, but also a structural element of education for sustainable development.

During the whole period of its existence Ukraine includes environmental education and enlightment in its state environmental policy. To a greater or lesser extent, the issue of environmental education was given attention in most of the political, legal, conceptual, legislative acts in the field of environmental relations. In particular, considerable attention was paid to the issues of environmental education in the Basic Directions of the State Policy of Ukraine in the Field of Environmental Protection, Utilization of Natural Resources and Ensuring Environmental Safety, approved by the regulation of the Verkhovna Rada of Ukraine on March 5, $1998^{29}$.

At the moment, the main legislative act that establishes the conceptual foundations of state environmental policy in Ukraine is the Basic Principles (Strategy) of the State Environmental Policy of Ukraine for the Period until $2020^{30}$, approved by the Law of Ukraine dated December 21, 2010. This Law provides the development of environmental enlightment for sustainable development Ukraine, which is currently an important political and legal guarantee of the inclusion of educational aspects in the environmental policy of all levels in Ukraine. Taking into account the existing world and European trends, both external and internal policies of Ukraine in the field of environmental education should be based on international legal principles and become a priority area of the state's activity in the field of development of environmental relations in the modern and the future. One of the problems of further improving environmental education for sustainable development, as a strategic direction of state policy, is its

\footnotetext{
${ }^{28}$ Скиба Ю.А., Лазебна О.М., Скиба М.М. Зміст і структура екологічної освіти в контексті сталого розвитку. Екологічний вісник. 2011. № 5. С. 25, $28-29$.

${ }^{29}$ Про затвердження Основних напрямів державної політики України у галузі охорони довкілля, використання природних ресурсів та забезпечення екологічної безпеки: постанова Верховної Ради України від 5 березня 1998 року. Відомості Верховної Ради Украӥни. 1998. № 38. Ст. 248.

${ }^{30}$ Про Основні засади (стратегію) державної екологічної політики України на період до 2020 року: Закон України від 21.12.2010. Офіиійний вісник України. 2011. № 3. Ст. 158.
} 
interdisciplinary nature, as it covers all the external, national, and regional fields of both educational and environmental policy.

\section{Universal character of right to environmental education in the system of environmental rights of the citizens}

In accordance with the established approaches in the theory of law, significant differences in the mechanism of the implementation of certain types of subjective rights exist due to their nature and content. While studying the peculiarities of realization of subjective rights V.V. Kopeichikov points out that the main reason for differences in the mechanism of realization of certain subjective rights lies in the object of administrative actions in the realization of citizens' rights, which is related to correct determination of correlation of interests of society and an individual, with the disposal of certain material goods and their transfer to the subject of law, with issues of the activities of certain state organizations (their staff, compentence, etc.) ${ }^{31}$. These factors explain the reasons for the differentiated approach to determining the mechanism for implementation of each type of subjective rights.

In its turn, the differences in the implementation mechanism take place also within the same type of subjective rights. Of course, this applies also to such kind of citizens' rights as environmental rights, in particular, the right to obtain environmental education, the mechanism of implementation of which depends on the level of the selected educational institution (in the case of formal environmental education), forms of education and other conditions. Different opinions are expressed in the special literature on this issue. For example, the mechanism for implementing the right to education is associated with the type of study chosen by a citizen, and with the total number of existing educational institutions and specialties in the country for which specialists are trained ${ }^{32}$. In any case, the fundamental legal basis for environmental education is the constitutional right of citizens to education. This means that the formal environmental education of Ukrainian citizens is received in educational institutions precisely in the exercise of their constitutional right to

\footnotetext{
${ }^{31}$ Копейчиков В.В. Реализация субъективных прав граждан. Советское государство и право. 1984. № 3. С. 13-18, 19.

Панкевич I.M. Здійснення прав людини: проблеми обмежування (загальнотеоретичні аспекти) : автореф.... канд. юрид. наук: 12.00.01. Львівський національний ун-т ім. Івана Франка. Л., 2000. 19 с.
} 
education. The right to environmental education is characterized by certain features, compared with the general right to education, and their coverage is an actual task of legal science.

Therefore, investigating the special place of the right to environmental education in the system of environmental rights of citizens, it is necessary to begin with the characteristics of the constitutional right to education. As you know, all constitutional rights are closely interconnected and interdependent. The realization of some constitutional rights and freedoms may serve as the basis for the realization of others. These provisions also apply to the right to education, since it is one of the necessary conditions for the comprehensive development of the individual, and its distinctive feature is the interrelation with other constitutional rights ${ }^{33}$. The right to education is the most important and necessary precondition for the implementation of many other constitutional rights. The right to education affects other constitutional rights of citizens, because the effective exercise of the right to work, the right to participate in the management of state affairs, entrepreneurship, information rights (socalled rights of the fourth generation) and many others necessitates the continuous improvement of educational level in accordance with the requirements of social development. The presence of a certain level of education in the subjects of implementation and provision of the rights of citizens can significantly improve the effectiveness of the implementation of law, the achievement of the ultimate goal, satisfaction of relevant interests. In some cases, the availability of appropriate education is a statutory condition for the exercise of certain rights. In such cases, the availability of relevant education becomes a legal fact for the emergence of relevant legal relationships.

In view of the above, one may conclude that the right to education is universal, owing to its security nature and the impact on the implementation of many other constitutional human and civil rights that most fully and objectively reflect the right to education in the system of constitutional human rights and citizen.

Taking into account the above-mentioned approaches to universality and guaranteeing the influence of the constitutional right to

${ }^{33}$ Орловский Ю. П. Конституционные гарантии права на образование в СССР. М.: Наука, 1986. С. 12. 
education for the exercise of other rights, one can conclude that the special and universal role of the right to environmental education in the system of subjective environmental rights. It should be borne in mind that most environmental rights determine and influence the realization of each other, and ultimately all together guarantee the fundamental natural absolute human right, i.e. the right to environmental safety.

It is precisely on the guaranteeing role of environmental education in relation to other environmental rights that attention is often drawn to the doctrine of environmental law. Yu.S. Shemshuchenko refers education and culture to ideological guarantees for the implementation of all environmental rights ${ }^{34}$. In the early 90's of the 20th century S.O. Bogolyubov and O.S. Kolbasov noted that one of the components of guarantee of the right to 'proper environment' is to get citizens the right to environmental enlightment and upbringing ${ }^{35}$. This is confirmed by the conclusion that 'all environmental rights are derived from the right to environmental safety and in the process of its implementation provide $\mathrm{it}^{36}$.' Environmental enlightment and upbringing is also considered as one of the forms of realization of the right of citizens to participate in the development and implementation of environmental measures in environmental law doctrine ${ }^{37}$.

In addition, it is noted that environmental education directly affects the provision of the right to environmental information ${ }^{38}$. As prof. M.V. Krasnova noted, the right to environmental education is really closely linked to the right to obtain environmental information, because 'education, culture, and spirituality cannot exist without information that mediates knowledge gained through the announcement of relevant information about phenomena, objects, activities ${ }^{39}$.' The right to environmental education and the right to environmental information are the most approximated ones in their content in the system of

\footnotetext{
${ }^{34}$ Шемшученко Ю.С. Правовые проблемы экологии. К.: Наук. думка, 1989. 25 с.

${ }^{35}$ Боголюбов С. А. Колбасов О. С. Закон об охране природы в СССР. Каким ему быть? Мнения и предложения ученых. М.: Юридическая литература, 1991. С. 27-28.

${ }^{36}$ Краснова М.В. Гарантії реалізації права громадян на екологічну інформацію : дис... канд. юрид. наук: 12.00.06. К., 1997. С. 18.

37 Андрейцев В.І. Екологічне право. Курс лекцій : навч. посібник для юрид. фак. вузів. К., 1996. С. 43.

${ }^{38}$ Краснова М.В. Гарантії реалізації права громадян на екологічну інформацію : дис... канд. юрид. наук: 12.00.06. К., 1997. С. 45.

${ }^{39}$ Краснова М.В. Там само. С. 128.
} 
environmental rights of citizens. Among the elements of the structure that causes such affinity, are the objects of these rights, i.e. environmental information and systematic environmental knowledge.

In our opinion, the right to environmental information may be considered as an element or competence within the subjective right to environmental education, since any educational information of an environmental nature will relate to the actual state of the environment or its objects, sources, factors, materials, substances, physical factors that affect the state of the environment and human health, environmental projections, plans, programs, state environmental policy, legislation on environmental protection the natural environment or other data, which by their legal nature are environmental information and are enshrined, as such, in Article 25 of the Law of Ukraine 'On Environmental Protection'. At the same time, it is important to realize that in the process of implementation these rights do not absorb one, since the purpose, legal procedures, the range of obligated actors, the legal basis and the consequences of their implementation contain significant differences that are legal criteria for their differentiation.

An essential feature of the right to environmental education, which determines its special place in the system of environmental rights of citizens, is its ability to be a prerequisite, a guarantee for the implementation of other environmental rights of citizens, as well as the fulfillment of their environmental obligations stipulated by the Constitution of Ukraine and sectoral environmental legislation. This conclusion is confirmed by the theoretical and legal provisions that any norm may be considered not only as an object of guarantee, but as a guarantee of other legal norms.

Consequently, the right to environmental education is interlinked with other environmental rights of citizens and may be considered as a guarantee or a condition for more effective implementation of some other environmental rights, such as the right to participate in the development and implementation of environmental protection measures, rational and integrated use the natural resources, the right to participate in the discussion and introduction of proposals for draft regulatory acts, materials for the placement, construction and reconstruction of objects that can negatively influence the state of the environment, making proposals to state authorities and local self-government bodies, legal entities involved in decision-making on these issues, the right to 
participate in public hearings or open meetings on the impact of planned activities on the environment on stages of placement, design, construction and reconstruction of objects, the right to conduct a public environmental expert examination, etc.

In addition, the realization of the right to environmental education can be a guarantee of citizens' compliance with their constitutional and sectoral environmental responsibilities.

\section{Legal aspects of environmentalization of educational relations}

In the environmental law doctrine it was noted that citizens have special powers in relation to one or another environmental law, depending on the content of the law, the main competencies of its subjects, the range of objects. Therefore, the actual task of legal doctrine in solving the problem of environmental education is to clarify the range of legal relationships that arise when implementing the right to environmental education, as well as subjects, content, objects of this right.

As mentioned above, realization of the right to environmental education of citizens in Ukraine is carried out within the constitutional right to education in the branch legal relations with a certain educational institution. Depending on the place in the structure of education in Ukraine, as enshrined in Art. 29 of the Law of Ukraine 'On Education', legal relations in the field of education are legal relations in the field, respectively, preschool, general secondary, extracurricular, vocational and higher education (relations of formal education).

This is a complex legal relationship, since each party has several powers and correspondence to their responsibilities. Relationships that arise with regard to training are time-consuming, the duration of their duration depends on various factors, and first of all, from the normative term of education at a certain educational level, established by law.

The grounds for the emergence, change and termination of legal relations in the field of education are legal facts, as well as complexes of legal facts, which are understood as the totality of legal facts necessary and sufficient for the legal consequences established by $\operatorname{law}^{40}$. In particular, such legal facts and cases are the procedures for entry or renewal in an institution, transfer from one institution to another, from

${ }^{40}$ Красавчиков О.А. Гражданское правоотношение / Советское гражданское право: В 2 т. М.: Высшая школа, 1968. Т. 1. С. 92. 
one form of study, a specialty, a direction of training or specialization to other, deductions from an educational institution. The procedure and conditions of admission, transfer, renewal to education are established by the legislation and local acts of educational institutions.

It should be noted that the legal fact that causes the actual exercise of the right to environmental education is the introduction into the educational process of the corresponding specialties, specializations, educational programs, degrees, directions of training or environmental disciplines (subjects, courses, lessons, classes, etc.) depending on the type and the level of the educational institution and the educational system. The form, content and scope of environmental education in educational institutions can be introduced both in the invariantional and variational parts of the educational process in accordance with educational standards, curricula, and various educational programs.

In our opinion, it is necessary to agree with the scientific proposals on the allocation of a special type of educational (or pedagogical) relations in the structure of educational legal relations. However, the question of the branch affiliation of the legal relationship, which consists of the study, is still debatable. In particular, along with the existence of constitutional, administrative, civil, labor, the existence of a separate group of special legal relationships, which form the core of the whole system of relations in the field of education, so-called educationaleducational or pedagogical legal relationships.

Obvious specificity of educational (pedagogical) legal relationships gave grounds for formation of a separate branch of "educational law" within legal science. One of the first scholars who expressed the idea of recognizing an independent branch of "educational law" was G.O. Dorohova in 1985. Unlike to the USSR, at that time the term "educational right" was already widely used in other socialistic countries. In our time, the accelerated development of the education industry and relevant legislation, the emergence of new legal institutions, led to a return to scientific discussions about the nature and sectoral affiliation of the norms governing this area of relations. The issue of formation of educational law is also the subject of scientific discussion in Ukraine. Separate scholars support the earlier hypothesis about the existence of an independent branch of educational law. Strengthening scientific research on the separation of educational law in the legal system of Ukraine will be important both for further 
improvement of the legal principles of environmental education and the reform of relations in the field of education in Ukraine as a whole. As Ukraine has declared in its conceptual political-legal documents the intention to implement environmental education, the modernization of education and the development of environmental education in the interests of sustainable development, educational law, as a branch of law, should become the basis for the real implementation of these provisions.

In our opinion, the range of social relations that are part of educational institutions is covered by the forms of educational process provided by the relevant sectoral legislation. For example, in the field of higher education, these are forms of educational process, which are established by Art. 50 of the Law of Ukraine 'On Higher Education', i.e. training sessions, independent work, practical training and control measures. These relations are central in the system of educational legal relations, which arise in relation to the reception of persons of education of the corresponding educational level, and it is exactly in these relations that the direct realization of the right of citizens to receive ecological education is carried out.

Educational and legal relations, as well as any other social relations, regulated by the rules of law, have their structure, the elements of which are the subjects, objects and content of such relations. As already mentioned, environmentalization should be present in all these elements.

Subjects (parties) of educational relations are educational institutions, pedagogical or scientific-pedagogical workers and persons studying. Tripartite character is considered to be a characteristic feature of the studied legal relations, since the actual educational and pedagogical relations that connect the teacher and the student can occur only with the participation of a comprehensive educational institution. ${ }^{41}$

The participants in educational and educational relations can be physical and legal persons, on the basis of which the state recognizes the ability to be the bearers of subjective rights and legal duties, in the field of education, giving them an appropriate legal personality.

${ }^{41}$ Тицька Я.О. Суб'єкти освітянських правовідносин. URL: http://legalactivity.com.ua/index.php?option=com_content\&view=article\&id=92\%3A2011 -10-04-23-17-59\&catid=1\%3A-1\&Itemid=9\&lang=ru (дата звернення 10.06.2019). 
As for individuals who are carriers of subjective rights in the field of education, Article 53 of the Constitution of Ukraine, which establishes the right to education, uses the term "everyone", that is, the subjects of this right in Ukraine are all persons, regardless of nationality. For citizens of Ukraine an additional constitutional guarantee of the right to education is secured. It is free to receive it at state and municipal educational institutions, including on a competitive basis, depending on the level of education.

The specific scope of the personality of a person in educational relations can vary significantly depending on the level of education. At different ages there is the capacity of people to study at different levels of education. For example, the opportunity to study at pre-school educational institutions arises almost from birth, because as stipulated in Art. 4 of the Law of Ukraine 'On Preschool Education' the preschool age begins with the infant's period and ends with the age of 6 (7) years. At the same time, for other levels of education, age limits are not established by the current legislation both regarding the minimum age and the maximum age of the acquisition of the corresponding education. This means that the general legal personality in the field of education arises from the person from birth and terminates with death. This conclusion describes simultaneously the possibility of obtaining environmental education in primary schools, which is not limited to an individual's age and exists throughout his life.

In the current legislation of Ukraine, there are no regulations on the eligibility and capacity of citizens in the field of education, in particular, regarding their occurrence and termination, possible grounds and order of their restriction, which is apparently one of the gaps in the legal mechanism of the constitutional right to education, one from the elements of which is the right to environmental education. It should also be noted that educational personality and the totality of rights and obligations in this field together with other elements form the content of the branch legal status of a citizen in the field of education. In our opinion, the right to environmental education is an integral element of the educational and legal status of person and citizen in Ukraine.

Educational establishments of all forms of ownership, types and levels of accreditation of the educational system of Ukraine have a special legal personality, which, accordingly, determines their special legal status, implementation of which is carried out in the educational 
and scientific spheres in order to provide conditions for obtaining persons who are studying, education of a certain educational, educational qualification level or degree. Thus, an educational institution is an entity created to ensure the implementation of the constitutional right of citizens to education, which takes place in the relevant legal relations. According to the results of licensing, attestation, accreditation, the Ministry of Education and Science of Ukraine, local authorities of education within the limits of their authority give educational institutions, regardless of the forms of ownership of the license, the right to carry out educational activities in accordance with state requirements, with the establishment of certain educational qualification levels of training, which correspond to personnel, scientific-methodical and logistical support, enter them in the state register of educational institutions of Ukraine.

One of the features of legal personality of a legal entity is the theory of law, which refers to the purpose of its creation, according to which a legal entity operates in a particular field. The objectives, tasks and directions of its activity may be determined by the legislation as determining the legal personality and legal status of an educational institution as a legal entity. For example, one of the main tasks of higher education institutions envisaged by Article 26 of the Law of Ukraine 'On Higher Education' is 'the formation of a personality through patriotic, legal, environmental education, the approval of participants in the educational process of moral values, social activity, civic attitude and responsibility, a healthy way life'. The appearance of the aforementioned norm in this law is nothing more than a manifestation of environmentalization of the educational sphere, namely of the content of the legal personality of higher educational institutions in Ukraine, and is an essential sign of changes in the social purpose of higher educational institutions in society.

When studying the legal aspects of environmental education, a significant interest from a legal point of view is the question of determining the objectrelations that arise in the field of environmental education, so the main focus in the analysis of these relations, we consider to focus on his discovery. After all, the very object of subjective law gives the answer to the question 'right to what?' provided by the legislation of the subject. As A.P. Dudin, 'legal norms establish the rights and responsibilities of the subjects of legal relations not 'in general', but in relation to a particular 
object, about which there is one or another relationship ${ }^{42}$. In our opinion, object reflects the specificity of relations in the field of environmental education in the most eminent way.

As is known, in the general theory of law objects of legal relations are recognized things, other tangible and intangible benefits, actions, results of actions, which are aimed at the activities of entities in the process of exercising their subjective rights and legal responsibilities; these objects are provided by the norms of law and connect the subjects in the legal relationship. The object of legal relationship should be fixed in such a quality at the legal and regulatory level.

At the scientific and doctrinal level, the issues of educational legal relations are not sufficiently investigated. In this regard, it should be noted that the decisive aspect of the subjective right to education is, for the most part, recognized 'the possibility of acquiring knowledge (or a certain amount of knowledge)', 'access to knowledge', 'improvement of knowledge', 'knowledge acquisition', etc. For example, the very essence of the constitutional right to education is understood as 'obtaining certain amounts of knowledge', and in relation to vocational training (including in a higher educational institution) - 'the amounts of knowledge, the quantitative and qualitative aspects of which vary, depend on the branch of economy, the future specialty ${ }^{43}$. The concept of 'environmental education' is deeply connected with environmental knowledge.

Consequently, the transfer of a certain amount of knowledge is one in which the activities of those who study (pupils, students, cadets, etc.), as well as educational establishments, their structural subdivisions, and scientific and pedagogical workers are carried out. The foregoing gives us the basis for conclusion that as a result of the process of scientific knowledge, it is knowledge is a final destination of the actions of the subjects of educational legal relations, that 'unites subjects of rights and duties in relation' that is the object of educational and educational legal relations. According to the existing classifications of objects of legal relationship, such an object can be attributed to the results of actions (behavior) of subjects.

42 Дудин А.П. Объект правоотношения (вопросы теории). Саратов: Изд-во Саратов. ун-та, 1980. С. 65.

${ }^{43}$ Дольникова Л.А. Право граждан на образование и организационно-правовые формы его обеспечения : Учеб. пособие. Уфа: Изд. Башк.ун-та., 1987. С. 26-27. 
One of the approaches to defining the concept of 'knowledge' as a philosophical category is its understanding as the result of the process of knowledge $^{44}$, as "proven practice and logically confirmed result of the knowledge of reality, its correct reflection in human thinking ${ }^{45}$, and not just as a system of certain educational information. Systemic and substantiated scientific knowledge is another essential feature that distinguishes scientific knowledge from the products of everyday cognitive activity of people ${ }^{46}$. This means that environmental knowledge, as an element of student consciousness and the object of legal relationship, must meet the criteria of scientific knowledge, that is, to be in scientific knowledge of its own nature. The criterion of "scientific" knowledge means its truth, authenticity, validity, and consistency. According to the Concept of Environmental Education of Ukraine, the formation of the very basic ecological knowledge is the main objective of environmental education. Indirect (general) object of these relations is environmentally safe, sustainable development of mankind, preservation of the natural environment and efficient use of natural resources for the benefit of present and future generations.

In our opinion, the concept of environmental knowledge as the object of legal relations in the field of education requires further research of its legal features and legal forms. In particular, one of the important signs of environmental knowledge is the requirements established by the legislation regarding their sources, as well as the forms of their objectification, which, in particular, may be standards of education, teaching and methodological documents, curricula and work programs, as well as textbooks, manuals and other educational editions, approved in accordance with the procedure established by law.

\section{CONCLUSIONS}

The main prerequisites for environmental education in Ukraine have become international, environmental and legal factors. International interest in the development of environmental education, active

\footnotetext{
${ }^{44}$ Савчук В., Сумятин В. О роли мнения, убеждения, веры в процесе познания. Сознание и знание. М.: Ин-т филос. АН СССР, 1984. С. 21-34.

45 Бауер М.Й. Екологічні знання у контексті формування світоглядних цінностей суспільства : дис. на здоб. наук. ступ. канд. філос. наук : 09.00.09. К., 1998. 60 с.

46 Введение в философию : Учебник для вузов. В 2 ч. Ч. 2. М.: Политиздат, 1989. C. 369.
} 
international and regional cooperation in this field, which has been under way for nearly 100 years, undoubtedly has an impact on Ukraine, its society and law. The concept of the United Nations Organization in the field of environmental education, which is currently reorienting towards education for sustainable development, has been reflected in many political, legal and legislative acts of Ukraine.

Environmental prerequisites for environmental education have become scale environmental problems of the global, regional and local levels, which continue to aggravate and require a deeper awareness of the negative processes occurring on the planet, changes in the paradigm of human existence in order to save lives and health of people and the environment.

Legal preconditions for environmental education are the growing role of law in solving environmental problems, the emergence of environmental law and legislation, legal consolidation of environmental rights of citizens, as progressive, humanistic advances in legal thought, including the rights of citizens to obtain environmental education. Of particular importance are the problems of the development of environmental and legal education in the formation of the right to environmental safety, which is an indicator of the achievements of modern environmental and legal culture of society and the state. Legal issues that exist in the areas of environmental safety, environmental protection, efficient use of natural resources and the implementation of environmental rights of citizens are of crucial importance for a proper understanding of the system of environmental and legal norms in the consciousness of all citizens, and especially in the legal sense of the specialists who provide realization of the right. The urgent need for the development, support and improvement of environmental science and education, the environmentalization of law and legislation, as an integral part of the mechanism of environmental activities, should deepen the environmentalization of legal education.

The development of legal regulation of environmental education in Ukraine takes place in stages. The most important factor that resulted from this process was the legal consolidation of the citizens' right to receive environmental education as one of the environmental rights of citizens in 1991 Law of Ukraine "On Environmental Protection". Subsequently, issues of environmental education were included in most of the conceptual political and legal documents that define the basis and 
direction of state environmental policy. The Ukrainian legislation on education is gradually being ecologically One of the most significant events was the inclusion of provisions for education in the interests of sustainable development into the new Law of Ukraine "On Education" dated September 5, 2017. In particular, the Preamble of this Law states that the purpose of education is the comprehensive development of man as an individual and the highest value of society, talents, intellectual, creative and physical abilities, formation of values and necessary for the successful self-realization of competences, education of responsible citizens, raising the educational level of citizens in order to ensure sustainable development country and its European choice. In addition, Article 5 on public policy in education states that financing education is an investment in human potential, sustainable development of society and the state.

An important step towards the environmentalization of higher education was the adoption of the Decision 'On Environmentalization of Higher Education of Ukraine with the Aim of Training Specialists for Sustainable Development' by the Board of the Ministry of Education and Science of Ukraine on November 27, 2015, in which the environmentalization of higher education was recognized as one of the priority directions of the Ministry of Education and Science of Ukraine and all educational institutions regardless of their subordination and forms of ownership (para. 2). In the abovementioned decision, the scientific-methodical council of the Ministry of Education and Science of Ukraine and the National Agency for the Quality Assurance of Higher Education were recommended to include the environmental competence of a specialist in the list of general competencies during the development of methodological recommendations for the preparation of higher education standards (para. 3). In addition, rectors of higher education institutions are recommended to include an environmental component in the content of academic disciplines in all areas of knowledge (para. 10).

Thus, there is every reason to hope that the greening of sectoral educational legislation will continue and become a reliable legal guarantee for the effective exercise by citizens of their right to receive environmental education. 


\section{SUMMARY}

The article is devoted to research of legal problems of environmentalization of education in Ukraine. The author considers the important legal precondition for environmentalization of the legislation on education in Ukraine the right of citizens to receive environmental education, which is enshrined in the Law of Ukraine "On Environmental Protection" of June 25, 1991. The main problems of legal regulation in the field of environmental education are analyzed, such as the absence of a special law, uncertainty with the basic terminology, the prevalence of acts of a recommendation nature that do not have binding legal force and do not directly regulate the influence on social relations.

Particular attention is paid to the right to environmental education due to the fact that it is universal one in the system of other environmental rights and environmental obligations of citizens. In particular, the presence of a subject of environmental education may be a prerequisite and affect the effectiveness of its implementation of many other environmental rights, and also be a guarantee of the fulfillment of their environmental requirements.

An indispensable legal guarantee of the implementation of the citizens' right to environmental education, the author believes environmentalization of the law on education in Ukraine, because it is precisely in specific educational legal relations with educational institutions citizens can receive environmental education. The environmental right and legislation can not directly influence the process by methods and means inherent in them. The author draws attention to the need to distinguish between such phenomena as environmental education, enlightment, propaganda, information, which are often unreasonably identified, although they have different legal nature and legal mechanisms for implementation.

It has been demonstrated how the environmentalization of educational legislation affects the content of certain elements of educational legal relations at various educational levels. Particular attention is paid to the characterization of environmental knowledge as the main subject of educational legal relations, as well as the prospects for the formation of educational law, which should become the legal basis for the development of environmental education and education for the sake of sustainable development in Ukraine. 
Having outlining the main stages of environmentalization of the legislation on education in Ukraine, the author predicts that this process will continue, which will guarantee citizens the real exercise of their right to receive environmental education and ensure the observance of personal and public environmental interests, which consist in the effective and rational use of natural resources, protection of the environment and ensuring environmental safety for the benefit of present and future generations.

\section{REFERENCES}

1. Draft Principles On Human Rights And The Environment, E/CN.4/Sub.2/1994/9, Annex I (1994). University of Minnesota Human Rights library. URL: http://www1.umn.edu/humanrts/instree/1994dec.htm (дата звернення: 14.06.2017).

2. Александрова С.М. К вопросу истории развития системы экологического образования. URL: http://izd.pskgu.ru/projects/pgu/ storage/conferences/2014_03/2014-03-72.pdf

3. Андрейцев В.I. Екологічне право. Курс лекцій : навч. посібник для юрид. фак. вузів. К.: Вентурі; 1996. С. 13; Андрейцев В.І. Новації еколого-правової освіти в Україні. Право України. 1998. № 5. С. 44-50.

4. Андрейцев В.І. Екологічне право. Курс лекцій: навч. посібник для юрид. фак. вузів. К., 1996. 208 с.

5. Анісімова Г.В. Здійснення громадянами екологічних прав : автрореф. дис. на здобуття наук. ступеня канд.юр.наук: 12.00.06. Харків: Національна юридична академія України ім. Ярослава Мудрого, 1996.

6. Балюк Г.І. Екологічне право України: Конспект лекцій у схемах (Загальна і Особлива частини) : Навч. посібник. К.: Юрінком Інтер, 2006. 192 с.

7. Балюк Г.І. Правове забезпечення екологічної складової сталого розвитку: проблеми законодавчого регулювання, створення екологічної столиці світу та удосконалення екологічної освіти в Україні. Вісник Київського Національного університету імені Тараса Шевченка. Серія «Юридичні науки». 2012. № 92. C. 9-13. 
8. Бауер М.Й. Екологічні знання у контексті формування світоглядних цінностей суспільства : дис. на здоб. наук. ступ. канд. філос. наук : 09.00.09. К., 1998. 60 с.

9. Боголюбов С.А. Колбасов О.С. Закон об охране природы в СССР. Каким ему быть? Мнения и предложения ученых. М.: Юридическая литература, 1991. С. 27-28.

10. Бринчук М.M. Внешние методологические основания развития экологического права: закономерности развития природы, положения общественных наук о взаимодействии общества и природы, потенциал природы. Экологическое право. 2011. № 1. C. $2-7$.

11. Введение в философию : Учебник для вузов. В 2 ч. Ч. 2. М.: Политиздат, 1989. 369 с.

12. Грицкевич С. Екологічні права в системі конституційних прав людини і громадянина. Право України. 2001. № 8. С. 54-57.

13. Грицкевич С.Г. Конституційні екологічні права людини i громадянина та їх забезпечення органами внутрішніх справ : автореф. дис. ... канд. юрид. наук: 12.00.06. К.: КНУ ім. Тараса Шевченка, 2002. 24 с.

14. Маркович Д.Ж. Глобализация и экологическое образование. Соииологические исследования. 2001. № 1. С. 17, 20-23.

15. Дольникова Л.А. Право граждан на образование и организационно-правовые формы его обеспечения : Учеб. пособие. Уфа: Изд. Башк.ун-та., 1987. 77 с.

16. Дудин А.П. Объект правоотношения (вопросы теории). Саратов: Изд-во Саратов. ун-та, 1980. $81 \mathrm{c.}$

17. Большак Л.І. Екологізація освіти як соціальна потреба сучасного суспільства : автореф. дис. ... канд. філос. наук: 09.00.10 / Нац. пед. ун-т ім. М.П. Драгоманова. К., 2012. 20 с.

18. Ибрагимов И.М. Основания экологического образования: философский анализ : автореф. дис. ... канд. филос. наук: 09.00.08. М., 1998. 120 c.

19. Кобецька Н.Р. Екологічні права громадян України: автореф. дис. ... канд. юрид. наук: 12.00.06. Львівський держ. ун-т ім. Івана Франка. К., 1998. 16 с.

20. Кобецька Н.Р. Екологічне право України : навч. посібник. K., 2007. 352 c. 
21. Концепція екологічної освіти в Україні, затверджена Рішенням Колегії Міністерства освіти і науки України № 13/6-19 від 20 грудня 2001 р. Інформаиійний вісник. Вищза освіта. № 9. С. $50-61$.

22. Копейчиков В.В. Реализация субъективных прав граждан. Советское государство и право. 1984. № 3. С. 13-18, 19.

23. Красавчиков О.А. Гражданское правоотношение / Советское гражданское право: В 2 т. М.: Высшая школа, 1968. Т. 1. C. 92 .

24. Краснова М.В. Конституція України та екологічні права громадян. Вісник Київського національного університету ім. Тараса Шевченка. Юридичні науки. 2000. № 8. С. 12-20

25. Краснова М.В. Гарантії реалізації права громадян на екологічну інформацію : дис... канд. юрид. наук: 12.00.06. К., 1997. 199 c.

26. Краснова М.В. Екологічні права та обов'язки громадян. Екологічне право України. Академічний курс : Підручник. К., 2005. $848 \mathrm{c}$.

27. Матвійчук А.В. Деонтологічний аспект екологічного знання. URL: http://www.filosof.com.ua/Jornel/M_59/Matvijchuk.pdf

28. Маца К.О. Роль екологічної освіти в формуванні нового наукового світобачення. Людина і довкілля. Проблеми неоекологї. 2000. Вип. 1. С. 10-15.

29. Об экологическом образовании и воспитании населения: Закон Республики Армения от 20 ноября 2001 г. Официальный сайт Национального Собрания Республики Армения. URL: http://www.parliament.am/legislation.php?sel=show\&ID=1741\&lang=rus\#

30. Об экологическом образовании и просвещении населения: Закон Азербайджанской Республики от 10 января 2002 г. URL: http://edu.gov.az/ru/pdf/72/2359

31. Об экологическом образовании населения: Закон Республики Таджикистан от 29 декабря 2010 г. URL: http://energo-cis.ru/ wyswyg/file/Zakon/Nacional/Tadghikistan/ob_ekologicheskom_obrazov anii_naseleniya.pdf

32. Орлов М. Правове забезпечення реалізації екологічних інтересів - основа належної охорони довкілля і розвитку економіки України. Право України. 2001. № 1. С. 68-72. 
33. Орловский Ю.П. Конституционные гарантии права на образование в СССР. М.: Наука, 1986. 176 с.

34. Офіційний сайт екологічної організації «Зелений порятунок». URL: http://www.greensalvation.org/old/Russian/ Publish/10_rus/10_16.htm (дата звернення: 14.06.2017).

35. Панкевич I.M. Здійснення прав людини: проблеми обмежування (загальнотеоретичні аспекти) : автореф.... канд. юрид. наук: 12.00.01. Львівський національний ун-т ім. Івана Франка. Л., 2000. $19 \mathrm{c}$.

36. Позняк Е.В. Культурна функція екологічного права: від декларативності до прийняття конкретних рішень. Вісник Національної юридччної академії України імені Ярослава Мудрого. 2012. № 3 (13). C. 210-215.

37. Шемшученко Ю.С. Правовые проблемы экологии. К.: Наук. думка, 1989. 25 с.

38. Про затвердження Основних напрямів державної політики України у галузі охорони довкілля, використання природних ресурсів та забезпечення екологічної безпеки: постанова Верховної Ради України від 5 березня 1998 року. Відомості Верховної Ради України. 1998. № 38. Ст. 248.

39. Про Національну стратегію розвитку освіти в Україні на період до 2021 року: Указ Президента України. Офіиійний вісник України. 2013. № 50. Ст. 1783.

40. Про освіту: Закон України від 5 вересня 2017 р. Офіційний вісник України. 2017. № 78. Ст. 2392.

41. Про Основні засади (стратегію) державної екологічної політики України на період до 2020 року: Закон України від 21.12.2010. Офіиіийний вісник України. 2011. № 3. Ст. 158.

42. Проект Закону України «Про екологічну освіту». URL: http://w1.c1.rada.gov.ua/pls/zweb2/webproc4_2?id=\&pf3516=2309\&skl=5

43. Савчук В., Сумятин В. О роли мнения, убеждения, веры в процесе познания. Сознание и знание. М.: Ин-т филос. АН СССР, 1984. $106 \mathrm{c}$.

44. Скиба Ю.А., Лазебна О.М., Скиба М.М. Зміст і структура екологічної освіти в контексті сталого розвитку. Екологічний вісник. 2011. № 5. С. 25, 28-29. 
45. Слепченко А.А. Забезпечення права на екологічну освіту громадян в Україні : монографія. Чернівці: Кондратьєв А.В., 2017. $188 \mathrm{c}$.

46. Тицька Я.О. Суб'єкти освітянських правовідносин. URL: http://legalactivity.com.ua/index.php?option=com_content \&view=article $\& \mathrm{id}=92 \% 3 \mathrm{~A} 2011-10-04-23-17-59 \& \mathrm{catid}=1 \% 3 \mathrm{~A}-1 \&$ Itemid=9\&lang $=\mathrm{ru}$

\section{Information about the author Slepchenko A. A. $\mathrm{PhD}$,} Assistant Professor at the Deparment of Environmental Law, Taras Shevchenko National University of Kyiv 60, Volodymyrska str., Kyiv, 01601, Ukraine 